\title{
In Sickness and in Health
}

\section{Narratives on Epidemics as Tools for Science Teaching in Secondary Schools}

\section{Andrea Revel Chion ${ }^{1} \cdot$ Agustín Adúriz-Bravo $^{2}$}

Accepted: 3 July 2021 / Published online: 16 August 2021

(C) The Author(s), under exclusive licence to Springer Nature B.V. 2021

\begin{abstract}
In the context of the current COVID-19 pandemic, we deem of importance the identification of what content is privileged in secondary schools around health and disease. From our point of view, a relevant task is to accompany science teachers in their transit from teaching information to be evoked to teaching knowledge on that content that enables students' action. Accordingly, our aims in this article are (a) to move away from the extended biomedical approach to teaching topics around public health which some authors consider reductive and (b) to explore instead a multi-causal and multi-referential approach, conveyed through narratives. We examine the potential of the narrative format to provide context, information and relations that we think are useful for students to explain, through adequate scientific models, some aspects of pandemics.
\end{abstract}

\section{Introduction}

The current COVID-19 pandemic plunged the world into a socio-sanitary situation that has its most comparable antecedent in the so-called "Great Spanish Flu" of 1918. ${ }^{1}$ It is of course the case that many other massive outbreaks of infectious diseases have occurred since that famous world spread of influenza (among the most recent: the emergence of HIV

1 e.g. https://www.bloomberg.com/graphics/2020-history-of-pandemics-coronavirus-covid-19

Agustín Adúriz-Bravo

aadurizbravo@cefiec.fcen.uba.ar

Andrea Revel Chion

andrearevelchion@gmail.com

1 GEHyD-Grupo de Epistemología, Historia y Didáctica de las Ciencias Naturales, Instituto CeFIEC, Facultad de Ciencias Exactas y Naturales, Universidad de Buenos Aires, $2^{\circ}$ Piso, Pabellón 2, Ciudad Universitaria, Av. Intendente Güiraldes 2160, (C1428EGA), Ciudad Autónoma de Buenos Aires, Argentina

2 CONICET/GEHyD-Grupo de Epistemología, Historia y Didáctica de las Ciencias Naturales, Instituto CeFIEC, Facultad de Ciencias Exactas y Naturales, Universidad de Buenos Aires, $2^{\circ}$ Piso, Pabellón 2, Ciudad Universitaria, Av. Intendente Güiraldes 2160, (C1428EGA), Ciudad Autónoma de Buenos Aires, Argentina 
on the west coast of the USA in the 1980s; bovine spongiform encephalopathy in the UK a few years later; the reappearance of endemic diseases in the Americas, such as ChagasMazza; or the severe acute respiratory syndrome outbreak of 2002-2004), but these perhaps differ from the current pandemic in the scale of the public measures taken to control them. Central characteristics of the COVID-19 pandemic are the high number of deaths in its first year (and counting) and the depression of the economy, which is most probably increasing the death toll in emerging countries. As an example, an early press release from the Economic Commission for Latin America and the Caribbean (ECLAC) ${ }^{2}$ stated that the pandemic would have impact on the countries of this region, which, as exporters of primary goods, would suffer reductions in their gross products due to the fall of the prices of commodities and the contraction of commercial exchange. It was estimated that, out of a total of around 620 million inhabitants in the region, the number of poor people would be rising from 185 to 220 million (90 million of them in extreme poverty), as unemployment rates soared. These are also "victims" of the pandemic.

In this complex socio-economic scenario, "quarantine" strategies that, with different styles, have been proposed by governments all over the world have had impact not only on the economy, but also on social, familiar and personal dynamics. The educational systems have not been the exception: education has been forced to reinvent itself, without any time for reflection, in order to preserve as much as possible the foundational pedagogical links between students, teachers and institutions. Education, now rapidly adjusting to "screens", is assisting to a transformation of "school culture"- the beliefs, traditions, practices, rituals, agreements and principles that this institution is determined to sustain in relation to its aims (Poore, 2005; Viñao, 2002). Traditional actor roles, operating logics, circulating modes of signification and communication, organisational and administrative discourse and knowledge legitimised and privileged are now under scrutiny and are heavily questioned. With this reorganisation of all aspects of school culture, our reflection on science education needs to take into account the constraints imposed by the spaces, times and formats in which teachers and students meet to share knowledge, ways of doing and values, but, much more importantly, the necessity to go beyond some "sanctioned" school practices towards sustaining a science teaching aimed at helping individuals and society navigate through the pandemic.

All levels of education, from kindergarten to university, have been forced to virtualise teaching. Science teachers are compelled to rethink their classes in digitally mediated formats, which supposes for them additional efforts of creativity and commitment, the requirement of adjusting available technologies to their teaching and the challenge of producing and managing coherent didactical (i.e. instructional) proposals in demanding conditions and with some of their students with vulnerable backgrounds. But, these changes brought up by teaching with new means in a new landscape do not seem so far to have impacted much on the selection of content to be taught:

[T]here are enormous and diverse developments taking place in all spheres of life that call on education to take account. Not necessarily by changing its operational mode or procedures [...], but by changing its content in terms of the subject matter and skills it invites the students to master. (Jónasson, 2016: n/p.; emphasis added)

\footnotetext{
${ }^{2}$ https://www.cepal.org/en/pressreleases/covid-19-will-have-grave-effects-global-economy-and-willimpact-countries-latin
} 
Thus, the status quo of the normative science curriculum seems one element of school culture impervious to change (cf., Mutegi \& Momanyi, 2020), even in times of a severe health crisis.

In 2007, Umberto Eco wrote an opinion article for the Argentinian newspaper La Nación under the provocative title of "¿De que sirve el profesor?" ("What is the purpose of a teacher?"). ${ }^{3}$ In it, he proposed critical reflection on the role of teachers in times when the Internet has made possible extensive public access to information, which is unique in the history of humankind. In the past, with schools reserved to a minority, validated information about the natural and social worlds circulated almost exclusively within their walls, and transmission made sense as a pedagogy. Current school sometimes seems interested in maintaining this foundational aim established "in prior eras of education when learning was conceptualised as the acquisition of facts and teaching as the transmission of information to be taken in and used «as is»" (Darling-Hammond et al., 2020: 100), and this done in unfair competition with the broad circulation of information outside its reach, facilitated by new technologies. Raw data, to which people get access with little effort, are still often privileged in educational evaluation and used to give credentials to students. And, the problem is that this amount of non-processed information serves for little more than being literally retrieved and used in non-productive ways; when forgotten (which occurs very rapidly), a few clicks are enough to get back to it. In this scenario, how could schools take full profit of the position accorded to them nowadays by society?

If we focus on the "knowledge" that school most frequently selects as object of teaching, a number of questions arise: to what extent does it provide understanding? What performances does it enable? What new questions can students pose and answer based on it? In the case of the current pandemic, is school biology (and are other subjects) preparing students to understand the links between human-induced ecosystemic degradation and the emergence of this "new" virus SARS-CoV-2? Biology tells us that bats are the natural reservoir of coronaviruses and other viruses (such as Ebola, Hendra, Marburg and Nipah), some of them representing serious hazard to human health (with fatality rates over $50 \%$ ); then, what questions and answers can students elaborate around this piece of knowledge in biology classes? And, in addition to this, how can "standard" biological content cope with socio-scientific issues such as whether "generalist" preventive measures are applicable in complex and sensitive contexts (populations under war fire, forced migrants and refugees, homeless people, shanty towns in densely populated urban areas, women suffering from gender violence, people with restricted access to drinking water, etc.). What disciplinary models has school provided students with in order to answer such questions? What kind of "informed decisions" would anticipate or recommend, for instance, a secondary student as a consequence of a science teaching mainly based on the transmission of technical information?

We want to base our critical reflection around the nature of knowledge on health and disease circulating in secondary science classes on the quality of the enabled scientific questions, model-based answers, and science-informed interventions (such as sound decision-making, sensible declarations of principles, pertinent community participation, active social commitment, collective demands to decision makers), having in mind that such questions, answers and interventions should be providing comprehension of the public measures taken to try and control the current pandemic. What would the robustness

3 https://www.lanacion.com.ar/opinion/de-que-sirve-el-profesor-nid910427/ (in Spanish). 
be of these "epistemic" operations on the basis of a list of "hard" biomedical data on the COVID-19 virus? Excessive focus on bullet points such as the cycle of the virus, its denaturalisation with commercial disinfectants or its rate of mortality per 100,000 cases do not seem enough to seriously discuss in class the socially thematised issue of how safe it is to return to the classrooms!

In the context of this pandemic, it is important to identify what content is privileged at school around health and disease and to accompany teachers in their transit from teaching information to be evoked to teaching knowledge that enables students' action in context. Our aim in this article is to discuss the nature of school knowledge on infectious diseases, recognising the dominant biological, or rather biomedical, approach to such content (considered reductive by many authors, and labelled as "biologism"; cf., Rocca \& Anjum, 2020) as an obstacle against a way of comprehending public health issues that could result more empowering for students. ${ }^{4}$ As an alternative, and building upon research from our group or conducted by other scholars, we will explore a multi-causal and multi-referential approach (in a sense that we will later precise) to these topics. In addition, we will examine the potential of "school scientific narratives" to provide context, information and relations that we deem necessary for students to explain and argue through theoretical models on key aspects of pandemics (whether from the past, present or future).

Thus, in the particular case of COVID-19, we align ourselves with those who advocate for the incorporation of an "integrated view" into school science (e.g. Reiss, 2020), understanding this in a similar way as El-Hani and Machado (2020: 3): "a view that goes beyond health sciences into the realm of other domains of academic sciences", and even of other modes of knowing. We will argue that narratives are a powerful vehicle to implement an integrated view in science classrooms.

\section{Biomedical Approach to the Teaching of Disease: Shortcomings and Suggestions}

Mythopoetic and magical-religious explanations of disease, invoking unbalances in cosmic order or intervention of divine agents, slowly gave way to biological explanation during the nineteenth century. Supernatural, intangible, transcendental or mysterious causes were replaced by living agents, "unveiled" by the spectacular advances of the natural sciences, with "notable" contributors such as Rudolf Virchow, Louis Pasteur and Robert Koch (Rocca \& Anjum, 2020). The enthronisation of "biologistic" explanations (cf., Carmona Moreno et al., 2005) that followed soon showed enormous efficacy to construct models around the notion of "contagion", which provided theoretical tools to prevent and control the spread of endemic diseases (Gershenson, 2015). But, in time, those strictly biological

\footnotetext{
4 In this article, we are not going to characterise students' mono-causal-and hence more or less deterministic-explanations of health and disease as "poor" or "unsatisfactory" (as reported in a number of available empirical studies, e.g. Mahajan \& Chunawala, 1999), since those explanations could have been legitimately generated within the framework of a "biologistic" approach to the topic that aimed at conceptual understanding of the key biomedical notions involved. Instead, we will contend that mono-causal, deterministic explanations circulating in the classroom are not aligned with current science curriculum expectations (set around contextualised and critical biology education, which includes the concept of "health literacy") and with the proclaimed aim of fostering students' ability to take, as citizens, informed decisions and effective courses of action founded on scientific knowledge. We thank an anonymous reviewer for their comments and suggestions on this crucial issue.
} 
explanations proved to be as mono-causal and reductive as those in the previous models (Oliveira \& Egry, 2000; Rocca \& Anjum, 2020).

Just before Pasteur, an "intermediary" model - a refined version of the ancient "miasmatic" conception of disease - contributed to hygiene in the private and public domains, through theoretically founded measures on overcrowding, quality of water and air and waste management. Post-Pasteurian hygienists went beyond this model with bold enthusiasm sparkled by the "discovery" of microbes. According to the ensuing perspective that reduced infectious disease to biology, the "efficient" cause sensu stricto should be sought in an external biological entity, with little attention to other factors (Oliveira \& Egry, 2000). This form of explanation is of course extremely powerful (Gershenson, 2015), but shows interpretive limitations through zooming in on host and agent, leaving out the treatment of questions such as why does the same disease not spread evenly among all susceptible subjects? Why do some human groups show much greater prevalence of a particular disease than other groups? What are the "distal causes" of endemics and pandemics? Or, why are some seemingly efficacious treatments rejected by patients? Attempting to answer these questions calls for an examination of the relations between health and culture.

In opposition to biologism, the social perspective on disease, proposed by Asa C. Laurell $(1982,2017)$ among other authors, includes a hard core of undeniable biological elements, but reformulates the admissible explanations through pointing at the many facets of the problem and incorporating the "historicity" of health. This historical character is linked to the processes of "appropriation" of nature by humans; those processes have specific traits in each society and period. Within each human group, the "conditions" of the processes depend on the specific insertions of the individuals in that group (Krieger et al., 1993; Laurell, 2017; Rodríguez, 1994).

Maglio (2008) resorts to the socio-historical perspective from critical epidemiology to understand the emergence and re-emergence of infectious diseases. These are conceptualised as having multiple aspects, which, if only seen from the traditional conceptual frameworks (microbiology, pathology, anatomy and physiology, etc.), are veiled in their complexity. Again, the idea is not to dismiss the contributions of classical "health sciences", but to recognise the educational limitations of this dominant reductionist approach. ${ }^{5}$ (It is worth noting that Maglio also warns us against the damage caused to medical theories by what he calls "cultural relativism", a reductionism that overrules biological aspects when explaining health and disease.)

The ahistorical approach of biological reductionism is also criticised by scholars in the history of medicine, since it ignores the socio-cultural factors that provide the context when explaining disease. Historical studies show that, in the recent past, many infectious diseases were controlled through an intervention on the social network (e.g. improving housing, reducing working time, reorganising educational institutions or prohibiting child labour: McKeown, 1988). Along this line, McKeown (1988) contends that the descent in infectious diseases brought up by giving access to better nutrition (or by other large-scale interventions) was as important as that associated to immunisation through vaccines.

\footnotetext{
${ }^{5}$ In his book, Paco Maglio (2008) calls this explanatory reductionism-strictly circumscribing to biomedical models- "biological positivism", concocting the term as an opposition to "cultural relativism"-the other reductionism that he identifies and denounces. Maglio's construct functions as a general, analogical label to designate theoretical approaches based on the convergence of the nineteenth-century positivism and "biologism", and especially on Auguste Comte's ideas, which would include, for instance, Cesare Lombroso's theory of genetic disposition in criminals and Carlos Octavio Bunge's general theory of law based on considerations of the early twentieth-century experimental psychology.
} 
In the 1960s, the mono-causal perspective on disease begins to weaken. René Jules Dubos, a French-American microbiologist with interest in ecology, had already pointed out to the need to conceive health integrating the physical and mental dimensions; he considered that both health and happiness were manifestations of the way in which an individual responds and adapts to the challenges of everyday life. He also contributed with the idea that the environment should be conceptualised broadly, including in it the social determinants that shape the dynamics of the processes of health and disease (Dubos \& Pines, 1965). Four decades later, the Ecuadorian epidemiologist Jaime Breilh (2003) will recognise those seminal contributions as central when thinking about public health.

Multi-factorial models assuming the convergence of various dimensions in the emergence of disease seem to constitute today the standard framework to interpret processes in the realm of human health (Rocca \& Anjum, 2020). Their superiority became apparent when epidemiology "transitioned" from the explanation of infections, which dominated the scene in antiquity, the Middle Ages and the beginning of modernity, towards the explanation of contemporary chronic conditions (Gershenson, 2015; Parascandola, 2011), such as heart disease, which involves cigarette consumption, elevated cholesterol, hypertension, stress, obesity and sedentary lifestyle as co-adjuvant factors. The challenge is to take profit from these advances in critical epidemiology for science education.

If we adhere to contextualised biology teaching that aims at "health literacy", the issue now would be to incorporate multiple perspectives to explain disease. The COVID-19 pandemic provides teachers with a privileged opportunity to reflect on the need to contextualise the scientific content to be taught. In particular, if we want to enable our students to explain the emergence and global spread of SARS-CoV-2, we have to establish relations between the environment-conceived as broadly as possible-and human health. We would need a multi-dimensional notion of the concepts of health and disease, examined through the use of "multi-causal" explanations and with the aid of multiple disciplinary references (Revel Chion, 2013a; Revel Chion \& Adúriz-Bravo, 2017).

In turn, the conception of health that we think is best for the biology curriculum should be anchored to a conception of the environment with ecological and social dimensions; this virtuous didactical interaction of conceptions would enable renewed ways to explore the nature and history of diseases so that biology learning empowers students for science-based action. The intertwined events that gave way to the emergence of the current COVID-19 pandemic share, with those that caused the Black Death in fourteenth-century Europe, an epistemological feature in order to be satisfactorily explained: in the past and in the present, no "causal" agent for diseases of this magnitude appeared and spread spontaneously and randomly, without the aid of the direct consequences of human activity on the environment. We will go deeper into the implications of this statement through the presentation of "narrative vignettes" (see Metz et al., 2007) on different epidemics.

The kind of biology teaching that we are advocating for should take into account the rich network of relations between large-scale human interventions on nature, mostly directed to obtaining resources, and the new material and social transactions that arise between those two "actors". From a cross-disciplinary study of that network, we can derive science stories (didactical narratives) to use as tools in our science classes: such stories would relate natural and social factors, and thus would require conceptual references from the realms of natural and social sciences. Analysing these multi-referential stories with our students would help them not only understand more aspects of the present COVID-19 pandemic, but also spot the conditions under which new infectious diseases could spread in the near future. 
In the particular case of the emergence and dissemination of COVID-19, the following could be a preliminary list of information that would be functional for students to construct "school scientific explanations", and that should therefore be integrated into a prospective narrative on the disease: (1) ecological information on potential reservoirs and intermediary hosts of SARS-CoV-2; (2) socio-economic aspects that shed light on human practices that account for the zoonotic jump (or, more technically, spillover) from those intermediary hosts to humans and for the rapid spread of the disease in a global scale; (3) a cultural perspective to understand trading practices involving living individuals of exotic species in the so-called "wet markets"; (4) socio-sanitary information on public control of livestock breeding and slaughter, along with, of course, (5) the contribution of biology to analyse the structure of the virus, its adaptations and its replication in humans; and (6) a view from the health sciences around rates of infection, morbidity and mortality of the virus, recommendable health practices, vaccination, etc. At an even more complex stage of explanation, we could also add: (7) psychological and sociological analyses to account for people's behaviours and emotions during the pandemic; for instance, their extended acritical acceptance of fake news.

\section{A Conception of Environment for Less Reductionist Teaching of Health and Disease}

Traditional ecological perspectives are insufficient for a social and historical approach to disease. Standard epidemiology assumes an ontology of four big explanatory categories: subjects, disease, time and place (understood as physical location and biotic conditions). Critical epidemiology points at the need of reconceptualising those categories: the ecological space is now recognised as the scenery for human activities, associated with many dimensions-workspace, consumption, political organisation, community interaction and culture, which all entail a subjective appropriation of space (Breilh, 2010). This expansion of categories constitutes what has been called an "ecosocial" perspective (Krieger, 2001).

Natural (physical) geography has resorted for two centuries to a more or less strict separation of nature and humankind. The nature to be studied was a "primary" nature, not "socialised" by human intervention, and usually ahistorical and acultural (Santos, 1978). Critical geography advocates for a conception of "place" that goes beyond mere physical location (Blomley, 2008), and considers geographical space as an active system of relations between subjects, linked to social practices, where health is also a variable (Santos, 1978, 1995). The system nature-society is seen as multi-dimensional, regulated by interdependent, articulated processes traversed by social relationships. Such economic, cultural and political relationships dictate the regulating logic of the ensemble: they determine the "ways of living" of humans, and therefore the forms of construction of different spaces (Breilh, 2010) where health and disease exist.

In turn, economics as a discipline explains different forms of resource appropriation that generate the general living conditions framing public health and, at the same time, put a variety of wild species in contact with one another and with humans, triggering zoonotic diseases. For instance, economic studies identify "hot spots" in the world map with elevated risk of emerging infections (Allen et al., 2017) due to intensive extractive or productive activities that in many cases are developed under little external control.

Contributions from anthropology illuminate the cultural space where subjectivities are constructed, exposing practices with native or exotic species, breeding, agriculture, 
community organisation, types of consuming, roles of women and minorities, etc. For instance, anthropological studies have highlighted relations between people and land in Latin America that differ from the Western canon; among these, we can mention the idea of "good living" ("suma qamaña" in Aymara, "vivir bien" in Spanish) in some communities in Bolivia (Ranta, 2016). This idea expresses the ecological concerns and territoriality of indigenous people, carrying their will for self-determination and recognition of cultural rights and their opposition to unjust and destructive ways of living and unhealthy and discriminatory practices. Suma qamaña advocates for a way of "living together" that is at the same time healthy and sustainable (Breilh, 2003, 2010).

With all these contributions, a conception emerges with ecosystems and human health as interacting objects, where processes that have biological entity but are "socially determined" take place (Krieger, 2001). Consideration of the social determination of health would be a key to avoid both biological and historical determinisms, which Nancy Krieger (2002) labels as "fatalistic" determinisms. The need emerges to recognise different relations between nature and society if we want to move away from biological and biomedical reductionisms in the science classroom; but how do we also avoid social determinism? According to Krieger (2001, 2002), we should conceptualise determinants as the specific and characteristic ways in which social conditions influence health, which can be, in turn, modified through well-founded action. Determinants are the "social factors" that provide constraining influences or boundary conditions (Porta Serra, 2016) to the development of disease without inexorably determining the output. In this sense, the striking opposition between the eradication of some diseases from rich countries and their endemic character in poor countries patently shows the strong gravitation of those social factors and their transformability (Estany, 2016).

Examining the previous example, determinants could then be seen as the "social causes" (Porta Serra, 2016) of disease, but Anna Estany (2016) remarks that only in an indirect (and, according to her, philosophically trivial) sense we could use that expression-when trying to reinforce the idea that all aspects of human life (including the strictly biological) occur in the frame of social structures. To illustrate this, she discusses the case of communities with high rates of hypothyroidism. Its "proximal cause" is iodine deficiency, which is related to diet (and cultural habits) and is treated with public health measures (e.g. iodised salt); this turns the prevalence and treatment of the disease into "social problems", but does not make society "cause" or determine the hormonal alteration.

\section{Epidemics in Science Lessons}

Although modern epidemiologists working from a biology-based framework are mostly concerned with current disease processes, "it can also be valuable to examine the diseases of history, both to understand long-term sociological and demographic changes and to better understand how diseases work over centuries" (Littman, 2009: 457). This is an especially pertinent argument for science education (cf., Reiss, 2020). We will present here a brief multi-referential account (which can be considered a narrative vignette) of the first rigorously documented epidemic in history, seen through the lens of the conceptions of health and environment that we have discussed in the 
previous section. This will show the mechanics of the approach that we are suggesting for secondary science/biology classes and, in particular, for the study of COVID-19.

\subsection{The "Loimós tõn 'Athēnõn" (Plague of Athens)}

In the spring of the year $430 \mathrm{BC}$, second year of the Peloponnesian War, the city of Athens was traversing its cultural apogee, yet under notable social inequity. Its leader Pericles assisted the poor with free wheat, subventions and donations, and even retributions for the assistance to festivities and assemblies. Probably more than 200,000 people ("non-citizens" such as slaves, labourers and refugees) had recently arrived into the city and lived in miserable, overcrowded settlements, where the outbreak of a massive and extremely lethal epidemic coming from Africa occurred (Dagnino S., 2011).

Many of those people had been forced by the Spartan occupation of the land around the city to take refuge inside the so-called "Long Walls"; to these, troops returning from the warfront were added. Overcrowding facilitated contagion, and the number of fatalities skyrocketed, first in the precarious settlements, then throughout all social classes (supposedly striking Pericles himself in a later outbreak). Confusion and discouragement rapidly took over the city and then turned into panic and chaos at the sight of corpses piled up in front of the temples. Civilians and soldiers sought shelter from the plague, arriving at the feet of the Acropolis. Health, wellbeing and safety of the Athenians were gravely resented, and finally around a quarter of the population succumbed amidst the total collapse of the much valued Greek institutions (Longrigg, 1980).

Current historians of medicine hypothesise that the Athens plague could have been typhus, bubonic plague, typhoid fever, scarlet fever, some kind of haemorrhagic fever or even a tragic combination of two or three of the previous ones (Cunha, 2004; Littman, 2009). Thucydides' account of the epidemic is justly famous; he, who suffered and survived the disease, described in detail the event and its aftermath. Interestingly enough for our educational arguments in this article, Thucydides' declared intention of such a vivid description of the plague was so that "it may be recognised (...) if it should ever break out again" (Thucydides, 1933: II, 48). According both to his narrative and to later reconstructions, the plague was very probably initiated in Ethiopia and moved north along the commercial routes, entering Athens through the port of Piraeus and exploding due to the siege of the city. This scheme repeats itself in many other moments of history: the dissemination of an epidemic through displacement caused by labour, commerce and war (cf., Kaniewski \& Marriner, 2020). People and virus "travelling" then constitute key agents of the narrative.

But, what were the reasons that barred the plague from being an even more catastrophic event in the Eastern Mediterranean? And conversely, what circumstances favoured that, centuries later, some diseases would scale up to the range of pandemics? To answer this, we should decidedly look into a process that progressively expanded and became more sophisticated: travel through international borders-first for exploration, conquest, trade of goods, religion and slavery, and later for business, tourism and education. Today, through airborne international travel, causal agents of diseases can be carried in a few hours from one point of the planet to another: the Ebola virus, for instance, could reach London in half a day flying inside a passenger without symptoms coming from Kampala, Uganda. Indeed, this very real possibility is at the basis of many not-so-fictional movies on devastating pandemics. 
The analysis of the case of the Plague of Athens shows that biology is insufficient to explain it as an epidemic event that marked the development of Europe. Contributions from life and health sciences in the field of archaeo-epidemiology are certainly indispensable to hypothesise about the nature of the causal agent, identify possible reservoirs and vectors, characterise the transmission and document the symptoms, among other issues. But, this is not enough to give answers to questions such as why does the outbreak occur during the "Golden Age"? How do plague and war relate? What was the role of commerce through Piraeus? And most importantly, how did the plague affect the whole of ancient Greek history, prompting the decadence of democratic Athens? We need conceptual references beyond natural sciences to introduce the study of this epidemic — or any epidemic — at school.

\subsection{Going Beyond What Life and Health Sciences Tell Us About COVID-19}

Coronavirus SARS-CoV-2 is in most probability a natural virus that "jumped" to humans in China at the end of 2019. The disease caused by it is dubbed COVID-19 (from "corona", "virus", "disease" and "2019"). As other coronaviruses, SARS-CoV-2 is transmitted through the virus-laden droplets and aerosols ejected from the mouth and nose of a sick person (who might be asymptomatic); these can directly enter mouth, nose or eyes of a healthy person; be airborne for some time; or deposit on fomites (Jayaweera et al., 2020). Most common symptoms at the onset of the illness are fever, cough, myalgia and fatigue (Grant et al., 2020). COVID-19 affects the respiratory system, triggering "severe acute respiratory syndrome" (SARS) and bilateral pneumonia, which shows "ground glass" opacities in CT chest imaging (Hani et al., 2020). Simple measures of spread control have shown to be quite effective when strictly followed: hand-washing with soap and water, cleaning of high-touch surfaces, coughing and sneezing into the elbow, face masks and, of course, physical distancing in the context of more or less restrictive lockdowns (Chu et al., 2020). To these measures, in late 2020, preventive vaccination was added.

As we said, these basic pieces of knowledge that teachers may present in their classrooms, and also what is being contributed day by day by extensive and accelerated ongoing research, are unescapable but insufficient inputs to generate an understanding of the disease that allows students to successfully interpret information in mass media, act in their everyday lives and participate in citizen debates. Technically accurate biological models are not enough to account for issues such as the conditions of emergence of the virus, speed of contagion, differential mortality rates, efficient styles of lockdown, vaccination plans or ways of moving into the "new normality". We need to set those models in "broader contexts" with "human factors" (Allchin, 1999); in order to capture these, social sciences and humanities (and other sources of knowledge) are required. Multiple dimensions of the disease should be examined in the science classrooms if we aim at a science learning that enables students to competently use scientific knowledge in front of a "socio-scientific" issue (Zeidler et al., 2005) of the magnitude of COVID-19. Those social, cultural, economic, even psychological dimensions can be introduced through carefully constructed narratives on the pandemic, with their "constituent elements" being filled in using multi-referential information on the disease. Thus, there will be characters (e.g. the mythic Chinese citizen eating their equally mythic "bat soup"), a setting (e.g. a large international airport in South America receiving fully booked flights 
from Europe), a conflict (e.g. authorities trying to contain the virus against the clock with ill-received restrictions on individual liberties), a plot (e.g. overburdened public hospitals leading to medical doctors deciding who is put on a ventilator), a point of view (e.g. elderly people expecting to be vaccinated by the government), etc.

\section{Narrating and Explaining Disease}

\subsection{Narratives in Science Education}

\subsubsection{The Power of Narratives for Disciplinary Teachers}

The introduction of concepts related to health and disease in biology classes using the multi-referential perspective that we have been defending faces a significant obstacle: the very character of biology teacher education, which is mostly mono-disciplinary (albeit integrating some physics, chemistry and mathematics). Discipline-based professional profiles are installed in secondary science teaching, and traditional school curricula have not challenged those, offering very few reasons for interaction between areas (Álvarez Méndez, 2000; Lenoir et al., 2001). It is only relatively recently that new content that goes beyond the classical compartments of school disciplines is prescribed in competence-based curricula aiming at citizenship education.

Traditional theory-based, and now more progressive model-based, school science curricula and programmes have put much of their emphasis in showing students how to apply canonical solutions to "epitomic" or "paradigmatic" disciplinary problems; the identification of this sustained curricular trend has led some authors in our field to talk about "normal science education", inspired in Thomas Kuhn's epistemological ideas (van Berkel et al., 2000). It is not that often, though, that more integrated theoretical perspectives on more "real" problems (as suggested in Ortiz-Revilla et al., 2020) are presented to students. Accordingly, they are usually left very much unaccompanied in front of the tasks of integrating content from diverse disciplines and transferring it to a variety of situations, some of them from real life, where decision-making occurs (Millar \& Osborne, 1998).

In face of this state of affairs, how can teachers design didactical strategies in which health and disease are taught through more integrated approaches, in dialogue with social sciences, humanities and even arts, as it is now prescribed in many countries in our region? If genuine inter-disciplinarity (as demanded by some or the more radical STEM proposals: Ortiz-Revilla et al., 2020) is necessary for meaningful science learning, then any innovative proposal will be restricted, for the moment, to the contexts where science teachers have such a background or can co-teach with other specialists in their classrooms. We need to explore viable alternatives; a few suggestions along this line will be presented in the last section of this article.

It is our contention that many science teachers are deterred from implementing a multireferential teaching of health and disease-and consequently retreat to their "comfort zone" of "biologistic" proposals-because of the weaknesses that they perceive in their pre-service education (Revel Chion, 2013b; Revel Chion \& Adúriz-Bravo, 2019). Accordingly, we have proposed the use of science stories for biology teaching (Adúriz-Bravo \& Revel Chion, 2017, 2019): well-constructed, powerful science narratives that can convey the key elements of different references that help explain the (re-)emergence of infectious diseases. For the last decade, we have developed research on the potentiality and impact 
of narratives in science teachers' professional development. We have implemented the use of science stories in three different settings: teachers' pre-service education, formal in-service education through courses and in situ professionalisation at schools. In the first two settings, we accompany and "scaffold" the creation or adaptation of stories that will be "embedded" in didactical units (i.e. teaching-learning sequences); we share with practising or prospective teachers criteria to assess the quality of narratives. In the third setting, previously existing or new stories are told by the participating teachers in their own classes, and results from these implementations are collectively discussed.

In previous publications (Revel Chion, 2013a; Revel Chion \& Adúriz-Bravo, 2014, 2017, 2019; Adúriz-Bravo \& Revel Chion, 2016), we have presented theoretical frameworks, justifying arguments, critical discussion and empirical results concerning these formative experiences. Our guiding hypothesis has been that science stories can be effective vehicles to "convey" content that is necessary for teachers (and subsequently for students) to explain and argue in a more integrated way around health and disease. One of our main results has been showing learning outcomes where teachers (and students) are able to construct explanations that are robust in two dimensions: in their use of biological models and in the quality of their argumentative structure (Adúriz-Bravo \& Revel Chion, 2017; Revel Chion \& Adúriz-Bravo, 2019). Here, we build upon this accumulated research in order to examine the nature and use of narratives on epidemics.

We consider that the potential of narratives for teaching health and disease resides in the balance they can achieve between the historical, psychological, political, social and biological factors that are interwoven in their very structure; in this sense, Selma Wasserman (1993) affirms that tales of cases are "inter-disciplinary" in themselves. The narrative style confers science stories their verisimilitude and enables them to present the multi-layered character of human experience-in this particular case, epidemics. Additionally, the pattern of facts, events, actions, actors, goals and contexts, which is easily recognisable, facilitates their memorability (Greenhalgh, 2016). For these reasons, we consider science stories on human diseases a privileged means for critical biology education: we can combine in the storylines a multiplicity and diversity of elements with explanatory power, taken from different referential frameworks.

We humans compile and share our own experiences in a narrative format, and our tales express concepts, actions and values through the construction of "possible worlds". In this sense, Jerome Bruner (1991) discusses the famous ontological problem of the nature of narratives: are they real or imaginary? His answer is that what is told is not in the world (even if the facts constituting the raw material may deploy in it): tales are our own creation aiming at different purposes-building suspense and intrigue, reporting our view on events, imagining what we would like to happen, proposing different endings for stories that already have one, highlighting the moral aspects, etc.

Beyond the ontological problem, the question on perspective appears: what is the point of view from which a story is told? Once the emitter positions him/herself, the resulting narrative might hide the existence of other positions, when it should alert us of precisely the contrary. Bruner (2003) exemplifies this idea in many contexts, including that of epidemics: he states that their impact on poor people is seldom narrated, since canonical narrators are epidemiologists, and not experts in economy or members of vulnerable communities suffering such impact. The multiplicity of (disciplinary) viewpoints is absent in a biology teaching dominated by the detailed study of causal agents, symptoms and treatments.

Identifying the perspectives of emission of narratives should lead, in turn, to the other essential issue that we have already mentioned: what are the aims of the emitter (for instance, Thucydides or the UN Secretary) when narrating about a disease? Any story 
constructed for science teaching should have a clear narrative intention: informing, convincing, alluding, deceiving, influencing, conditioning, scaring, etc. In our didactical designs, the main aim is changing students' theoretical perspective: equipping them with conceptual tools for the production of scientific explanations in context.

Additionally, if human experience structured in narrative format is "read", as David Lodge (1992) suggests, in order to broaden and deepen our knowledge and understanding of the world, then a more "vital" involvement in learning can result from the use of science stories as a way to organise and transmit school scientific content that has tangible socio-scientific impact. The attraction that such stories will exert on studentsbased on the "natural affinity" of human minds for narrative (Hsu, 2008)—could generate, when teaching scientific concepts related to pandemics (see Metz et al., 2007): increased interest, meaningfulness of concepts, development of key competences related to inference and argumentation, positive attitudes towards science, enhanced applicability and transference of what is learnt and valuable insights on the nature ("epistemology") of the scientific enterprise. We will briefly return to this last point in the conclusions of the article.

\subsubsection{Which Characteristics of Science Narratives Justify Their Inclusion in Science Lessons?}

Bruner (1990) states that the most important property of narratives for educational purposes is that they are inherently sequential: narrative texts are constituted of a temporally arranged succession of facts, events, actions, results and the related mental states. This sequentiality appears to be the cause of the interest, comprehensibility and memorability that this kind of texts achieves in their recipients: their very structure activates in the audience a wish to solve an unbalance originated in (or rather, by) the story (Lodge, 1986).

According to the American linguist William Labov (2010), narratives in their minimal structure are composed of clauses whose order of concatenation more or less coincides with the sequence of the narrated events in time. Thus, narrative structure is established by the existence of temporal conjunction between independent clauses, so that those clauses cannot be rearranged without altering the original semantic interpretation of antecedence and consequence. But, this core sequence of time-ordered propositions is usually embedded in a bigger and more complex structure with distinct sections: abstract, orientation, coda, etc. At the heart of a tale organised like this lie the "complicating action" (the actual occurrences that move the story ahead by changing the accepted state of affairs: Lodge, 1986), the narrator's "evaluation" of the purpose and importance of the narrative and the "resolution", where the narrator indicates that the story has come to its closure. Labov's model guides the construction of our narratives for science teachers: its constructs will be recognised in the abridged narrative vignettes that follow.

Additionally, another characteristic of narratives which is highly "foreign" to, but actually very refreshing for, science classes is the variety of stylistic figures employed (metaphors, metonymies and synecdoches, among others), which make them more efficient than expositions and explanations in terms of comprehension and retention (Bruner, 1990, 1991; Norris et al., 2005). This turns the narrative style a precious tool for science teaching.

In the field of science education, Avraamidou and Osborne (2009) give value to the fact that "purpose" is always clear-cut in narratives-and this, in science classes, can be collaborating with the understanding of facts in the natural world. Science stories may 
be able to achieve that particular purpose through the use of "agents" that can be human characters who students can relate to, but also non-human entities (such as atoms, cells, rocks or stars) involved in an elaborate plot. The recipients of science narratives are expected to interpret these texts as stories by identifying in them features such as causality, intentionality and temporality, which are usually banned from nomothetic explanations, but the idea is that they, at the same time, recognise the explanatory (as opposed to the merely "decorative") value of those stories.

\subsubsection{How Can Science Teachers Construct Their Science Narratives?}

In order to capture and sustain attention of the targeted audience (students), the initial events of a science story should always conserve a tight connection to the rest of the text: they must constitute an indispensable contribution for the deployment of the plot. In a way, they should be selected at the end of the process of construction of the narrative. If the classical epistemological account of the nature of science emphasised its predictive character, the elaboration of a science narrative is founded on processes of retrodiction (Martin, 1986): the very end of the temporal sequence (the phenomenon that we want to explain) determines the selection of all other events (facts, interventions and ideas) to be included in the text. When narrating large-scale diseases, and this is applicable in the case of COVID19 , the general fact that they eventually become epi- or pan-demics is what gives "retrodicted" meaning to every piece of the ensemble. This entails including in their narration accidents and mishaps but also, and much more importantly, human decisions, policies and blunders.

In accordance with this retrodictive conception of narratives, Norris and colleagues (2005) suggest that the fact that the plot arises from contingencies woven with causally necessitating events should be profited in science teaching. Thus, in a science story, some facts transparently appear to cause, or to be caused by, others, while other events, when encountered for the first time by the recipient of the text, do not show predictable consequences. These "contingent" occurrences only make sense retrodictively:

[A]s the story unfolds, as the number of associated events increases, readers can begin to perceive and understand the interconnection among those events and grasp how what is happening to characters is a result of what came before. (Norris et al., 2005: 539)

In the case of COVID-19, the highly changing (and not too seldom contradictory) decisions taken, and recommendations issued, by governments or organisations during the many months of pandemic are now being critically scrutinised in order to ascertain their possible negative impact in its management. ${ }^{6}$ These controversies provide materials for the identification of contingent events to be included in a prospective narrative of the disease.

Labov's theoretical framework, as we have advanced, may be a useful tool to help teachers produce narratives with educational value. Labov (2010) uses the concept of "reportable" events: those whose narrative presentation is justified and which claim for attention. In this sense, there are some events that are more reportable than others, "relative to the situation and the relations of the narrator with the audience" (p. 547). For a science story

\footnotetext{
6 See, as an example of this, the controversy over the early alerts sent by Taiwan's Centers for Disease Control to the WHO regarding the possibility of human-to-human transmission of SARS-CoV-2 (www.cdc.gov. tw/En/Bulletin/Detail/PAD-lbwDHeN_bLa-viBOuw?typeid=158).
} 
to be "credible", it must contain many more events than only those that are reportable. And, teachers will not typically begin narration at the most reportable events; rather, they would need to start by showing how such events came about, and this will require going backwards in time to ascertain some precursors. In this process of navigating the network of events in reverse, teachers will reach a "triggering" event in the core of the narrative that is optimal to make it move forward (e.g. Maria Skłodowska noticing the irregular radiation emitted by Bohemian pitchblende, Wegener composing a puzzle with the figures of continents, an HIV + flight attendant travelling back and forth between Europe and North America and a remote-controlled robot landing on the surface of Mars). They can also add some "mundane" events prior to the trigger, to be located in the sort of introduction called "orientation". This Labovian mechanism of narrative "preconstruction" is identifiable in the narrative sketches provided in this article.

\subsection{Perspectives on Health and Disease in School Narratives on Pandemics}

\subsubsection{At the Beginning, It Was Ducks...}

The 1918 influenza outbreak - technically, the first pandemic in the history of humankind, since it was registered in the "old" and "new" continents at the same time-was caused by the virus A/H1N1, seemingly of avian origin. During the last year of World War I, an extremely virulent strain of flu rapidly extended throughout the planet, being particularly deadly in Europe and the Americas (Oldstone, 2009). An estimated 50 million people perished. Spain, which was neutral in the war, did not censor the crudely gruesome pieces of news on the disease in the newspapers, and this is the reason why this pandemic was dubbed "Spanish flu" (Pumarola \& Antón, 2018).

In March of 1918, an American soldier attended the infirmary at Camp Funston, Fort Riley, Kansas, with fever and asthenia; days later, hundreds of soldiers there would experience the sudden onset of flu-like symptoms, together with neurological signs and haemorrhagic fever. In April, US troops disembarked in Europe, taking with them the virus and sparkling the first "wave" of the flu. The main factor for the expansion of the disease was, in this case, the globalisation of the armed conflict: the virus moved at the pace of the military. A classical hypothesis, attributed to French virologist Claude Hannoun, locates the origin of the virus in China, appearing as a mutation of an avian virus in farm ducks (Langford, 2005). The original virus could have been transmitted directly or indirectly to humans, mutating several times, and arriving in the USA and Europe (Tornali et al., 2020).

Traits of this war-massive mobilisation and trenches-are a key to understand the rapid contagion of the disease. The accompanying scarcity of food (some pictures from that time show people capturing wild game to eat), soldiers' exhaustion and deficient sanitary services served as cauldron for weakened immune systems. Death occurred both from primary flu-virus pneumonia and from secondary pneumonia due to bacterial superinfections.

This very short sketch of a narrative (beginning with a triggering event à la Labov) is an extract of what we would actually tell in class accompanied with images ${ }^{7}$ (pictures, maps, diagrams); it intends to present the various references that we deem important to account for this pandemic, integrated into the storyline by means of the constituent elements that

\footnotetext{
7 The COVID-19 pandemic has rekindled public interest in the Spanish flu, and a huge number of photographs have been recovered and recirculated. See, for instance, Navarro (2010).
} 
characterise the narrative format (plot, conflict, agency, dénouement, etc.). The historical circumstances dominate the plot, pointing at the idea that the very "design" of World War I in Western Europe-large-scale ground war and intensive use of trenches-accounts for the dispersion of the disease. The subsequent "globalisation" of the conflict helps explaining how the Spanish flu arrives in territories far away from its epicentre, such as India or New Zealand. The entire story is "woven" or "knitted" (and that is precisely the etymological origin of the word "text") around a chronological sequence of events that starts with the semi-fictional "patient zero" and ends with scenes of horror and devastation.

Within the multi-referential frame provided by the narrative, the contribution from biology is essential: it sheds light on the contagiousness and mortality of the virus, on the weakening of the immune systems that predisposed patients to opportunistic infections, and especially on the possible interpretations of the process of spillover (Quammen, 2007) from ducks to humans. But, this spillover develops against the backdrop of production practices in Chinese poultry farms and initiates a cascade of necessary and contingent events that seizes the whole planet in a year; this makes other disciplinary contributions indispensable. It seems the case that very few other didactical tools can help students remember and retrieve the key elements that, in our view, are necessary for them to construct explanations on the Spanish flu... that, in turn, can be satisfactorily transferred to other problems of public health in a way that enables theoretically founded action.

\subsubsection{Then, It Was Civets}

The 2002-2004 SARS was "the first pandemic transmissible disease of previously unknown aetiology in the twenty-first century" (Wang \& Eaton, 2007: 325). The causing agent, an RNA virus named SARS-CoV, also belongs to the group of coronaviruses (very extended in mammals and birds), like the one responsible for the present pandemic. Additionally, four previously known viruses of the group are the cause of a fraction of human "common colds". The outbreak of SARS provoked by this virus, which began in November of 2002, surprised the specialists for its particularly aggressive character (Groneberg et al., 2005).

Cross-species transmission of SARS-CoV initiated in the province of Guangdong, in the south of China, in wet markets where wild civets and other animals sold for human consumption were killed and butchered in situ (Xu et al., 2004). How did the virus get to mammals? Scientists eventually identified horseshoe bats (genus Rhinolophus) as best candidates for natural reservoir of SARS-like coronaviruses (Wang \& Eaton, 2007). Many characteristics of bats (colonial nature, population structure, seasonal migration, daily movement patterns, roosting behaviour, etc.) make them "exquisitely suitable hosts of viruses and other disease agents" (Calisher et al., 2006: 531).

A well-constructed narrative on this SARS-CoV episode would show students the great hazard involved in close contact of humans with wildlife that is illegally brought into towns and manipulated without sanitary control, taking into account that our scientific knowledge of the diseases suffered and transmitted by many animal species is recognisedly small. Human invasion of the habitats of wild fauna modifies spaces and relations and exposes us to viruses unknown to our bodies; without immunity and treatment, once one of these "emergent" diseases breaks out, it has all the ingredients to become the "perfect storm".

How do we give shape to the narrative? Biologists and medical doctors need to be among the main characters: without considerations from evolution, molecular biology, 
ethology and virology, the transit from bats to humans will certainly be "blackboxed". But, we also need other voices carrying different (and sometimes conflicting) points of view: how can students comprehend the whole process and "close the circle" of its explanation without a discussion of human activities (e.g. traffic of exotic species) or cultural traits (e.g. alimentary habits). Finally, the "credibility" that we can give to the narrative by means of its "likeness with real life"-achieved by infusing into the tale a number of mundane and not-so-reportable events-will be a central asset for the impact of our science story on students.

\subsection{3 ... And in the End, Camels}

Finally, we will present some notes for the construction of a narrative on Middle East respiratory syndrome (MERS). The biological reference is, once again, that of zoonosis. But, the setting of the first known outbreak of this disease in the Arabian Peninsula in 2012 makes it necessary to incorporate references to the cultural viewpoint: practices that lead to close contact between humans and camels and, to a lesser extent, to the facilitation of horizontal transmission.

MERS is attributed to yet another type of coronavirus, designated as MERS-CoV. Many of its symptoms are common with other lower respiratory tract infections, and the disease differentially affects people of advanced age and/or with underlying comorbidities (Widagdo et al., 2017). It was first identified and communicated in Saudi Arabia in September of 2012; all registered cases up to date have been either in the Middle East or involving individuals who visited the region. Differing from other coronaviruses, MERS-CoV has high mortality and low rate of infection: it requires prolonged and close contact between patients for propagation, such as in the case of health-care settings. Viral circulation in the region should be understood in terms of both zoonotic events putting in contact bats and camels in Africa, and cultural patterns involving the use and trade of camels or, more arguably, the movement of infected people (Memish, 2016).

Upon the identification of the new disease, exhaustive serological search was conducted in different animal species; in the end, dromedary camels were studied, showing that up to $90 \%$ of those animals in the region had been exposed to the virus, and were consequently the best candidates to being the source of human infections. Taking into account that practices involving these animals date from several centuries ago in the peninsula, the scarce serological evidence of viral circulation in humans with "occupational exposure" to the animals (camel workers, handlers, butchers) provides strong evidence in favour of the idea that cross-species transmission is a rare event (Bratanich, 2015). This, together with the observation that horizontal transmission is also rare (Bratanich, 2015), would explain the strong confinement of the epidemic to this particular area of the globe.

Additionally, cultural studies on society and religion also become a relevant source if we want to explain how the MERS outbreak has affected the organisation and dynamics of the Hajj, the massive annual pilgrimage of Muslims to the holy city of Mecca in Saudi Arabia, with over 2 million participants. It is in all the previous information of mixed disciplinary origins where we can identify "reportable" events for our science story on MERS, conveyed for instance with the aid of the notion of exoticism, understood as an attraction towards the mystique and fantasy surrounding foreign cultures. 


\section{Conclusions}

In a previous section, we have stated that the mono-disciplinary profile of most secondary science teachers imposes a constraint on their intentions to present a multi-referential model of health and disease, and we have proposed that narratives are a possible way out. But, where will teachers collect the multiple references for their science stories? We envisage two different mechanisms to do this, which can support one another. The first one is seeking professional advice from colleagues at school or from other institutions; the second is the search for validated multi-referential sources.

In relation to the first mechanism, there is of course the possibility of designing inter-disciplinary projects and/or implementing co-teaching in the classroom, which will operate through standard curriculum borders. Here, we are thinking of something more modest: the establishment of fruitful professional links of collaboration with other teachers, researchers or experts that can help science teachers select, construct or assess their narratives. Once a science/biology teacher identifies a current or historical "event" of disease that seems powerful for educational purposes, informants from the field of social sciences, humanities or other disciplines can volunteer to provide ideas and materials for the story plan and revise the quality of the resulting product.

The other mechanism recognises that good science teaching, just as good scientific practices and their diffusion and communication, sometimes transcends the labels of specialities (Porta Serra, 2016). Porta Serra illustrates this idea with the work of iconic authors "in between fields" such as American geographer Jared M. Diamond (b. 1937), American palaeontologist Stephen Jay Gould (1941-2002) and British neurologist Oliver Sacks (1933-2015). To these, we add a short list of authors (Table 1) who have provided valuable matter for our science stories. These authors can be roughly divided into two big groups: scientist with specialised disciplinary background, who use a variety of sources and resources in their texts for general audiences, and fiction and non-fiction writers with solid scientific bases. In our experience, these authors provide extremely rich narrative material that, more or less adjusted, can be integrated by teachers into their science stories.

Once a science story is produced and assessed through the two mechanisms described above, teachers would need a more or less explicit accompanying worksheet of activities, to be developed before, during and after the narration. In our view, a sequence of carefully designed activities provides the ideal opportunity to work with alternative explanations on a given disease and with voices from communities of stakeholders outside the realm of formal disciplines. We could, for instance, contrast the multiple scholarly references in the narrative with misconceptions, folk knowledge, social images, dissident voices in debates, indigenous knowledge, myths, fake news, etc.

Additionally, a robust didactical proposal to work with/on the science story enables the discussion of some of the many salient features of the nature of science: the problems of objectivity, universality and neutrality; the different methods used to propose and validate pieces of scientific knowledge; the fabric of theories as representations; the role of debate, argumentation and negotiation; the nature of evidence and proof; the historicity of scientific theories; the ethos of the people who do science; etc.

The very rationality of narratives, which is contextual, situational and - in many of our examples-historical, can simultaneously unveil for students the internal and external processes of development of science, forgotten in its "final-form" presentation that usually occurs in teaching. A narrative-based approach to science education moves to the forefront 


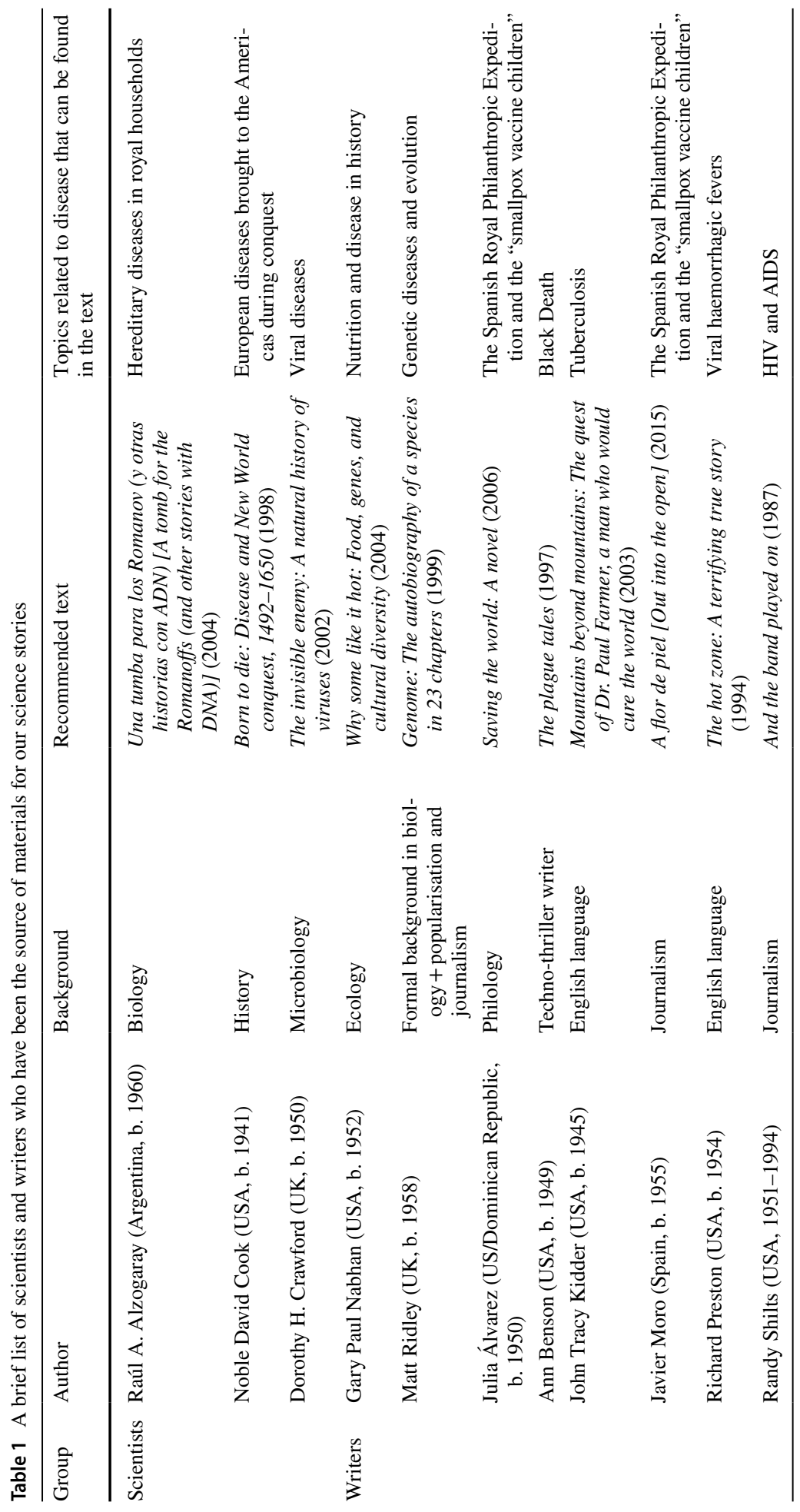


considerations on the nature of science as an activity, which, as we point out, connects the dynamics of knowledge production with its conditions of existence. This is achieved through the introduction of the classic "context of discovery", i.e. by means of examining the unique nature of each case in terms of the inferences, discourses and interventions made by scientists in their environment. Thus, the "human factor", rhetorical elements, ideologies, "materiality" of observations and experiments, cultural constraints, gender issues, etc., function as an accompanying text (figuratively, "cum textum") that helps students make full sense of the biomedical theories and models on health and disease.

\section{Declarations}

Conflict of Interest The authors declare that they have no conflict of interest.

\section{References}

Adúriz-Bravo, A., \& Revel Chion, A. (2016). El pensamiento narrativo en la enseñanza de las ciencias [Narrative thinking in science teaching]. Inter-Ação, 41(3), 691-704.

Adúriz-Bravo, A., \& Revel Chion, A. (2017). On the construction of "biology stories": The value of historical narratives for biology education. Paper presented at 2017 Meeting of the ISHPSSB-International Society for the History, Philosophy and Social Studies of Biology and the ABFHIB-Associação Brasileira de Filosofia e História da Biologia. Sao Paulo, Brazil.

Adúriz-Bravo, A., \& Revel Chion, A. (2019). On the construction of "science stories": The value of historical narratives for science education. Paper presented at ESERA 2019-International Conference of the European Science Education Research Association. Bologna, Italy.

Allchin, D. (1999). The tragedy and triumph of Minamata: A paradigm for understanding ecological, human-environment and culture-technology interactions. American Biology Teacher, 61(6), 413-419.

Allen, T., Murray, K. A., Zambrana-Torrelio, C., Morse, S. S., Rondinini, C., Di Marco, M., Breit, N., Olival, K. J., \& Daszak, P. (2017). Global hotspots and correlates of emerging zoonotic diseases. Nature Communications, 8, 1124. https://doi.org/10.1038/s41467-017-00923-8

Álvarez Méndez, J. (2000). Didáctica, currículo y evaluación: Ensayos sobre cuestiones didácticas [Didactics, curriculum and evaluation: Essays on didactical topics]. Miño y Dávila Editores.

Avraamidou, L., \& Osborne, J. F. (2009). The role of narrative in communicating science. International Journal of Science Education, 31(12), 1683-1707.

Blomley, N. (2008). The spaces of critical geography. Progress in Human Geography, 32(2), $285-293$.

Bratanich, A. (2015). MERS-CoV: Transmisión y el papel de nuevas especies hospederas [MERS-CoV: Transmission and the role of new host species]. Revista Argentina de Microbiología, 47(4), 279-281. https://doi.org/10.1016/j.ram.2015.11.001

Breilh, J. (2003). Epidemiología crítica: Ciencia emancipadora e interculturalidad [Critical epidemiology: Emancipatory science and interculturality]. Lugar Editorial.

Breilh, J. (2010). La epidemiología crítica: Una nueva forma de mirar la salud en el espacio urbano [Critical epidemiology: A new way of looking at health in the urban space]. Salud Colectiva, 6(1), 83-101. https://doi.org/10.18294/sc.2010.359

Bruner, J. S. (1990). Acts of meaning: Four lectures on mind and culture. Harvard University Press.

Bruner, J. S. (1991). The narrative construction of reality. Critical Inquiry, 18(1), 1-21. https://doi.org/10. $1086 / 448619$

Bruner, J. S. (2003). Making stories: Law, literature, life. Harvard University Press.

Calisher, C. H., Childs, J. E., Field, H. E., Holmes, K. V., \& Schountz, T. (2006). Bats: Important reservoir hosts of emerging viruses. Clinical Microbiology Reviews, 19(3), 531-545. https://doi.org/10.1128/ CMR.00017-06

Carmona Moreno, L. D., Rozo Reyes, C. M., \& Mogollón Pérez, A. S. (2005). La salud y la promoción de la salud: Una aproximación a su desarrollo histórico y social [Health and health promotion: An approximation to its historical and social development]. Revista Ciencias de la Salud, 3(1), 62-77. 
Chu, D. K., Akl, E. A., Duda, S., Solo, K., Yaacoub, S., \& Schünemann, H. J. (2020). Physical distancing, face masks, and eye protection to prevent person-to-person transmission of SARS-CoV-2 and COVID19: A systematic review and meta-analysis. The Lancet, 395(10242), 1973-1987.

Cunha, B. (2004). The cause of the Plague of Athens: Plague, typhoid, typhus, smallpox, or measles? Infectious Disease Clinics of North America, 18, 29-43.

Dagnino S., J. (2011). ¿Qué fue la plaga de Atenas? [What was the Athens plague?] Revista Chilena de Infectología, 28(4), 374-380.

Darling-Hammond, L., Flook, L., Cook-Harvey, C., Barron, B., \& Osher, D. (2020). Implications for educational practice of the science of learning and development. Applied Developmental Science, 24(2), 97-140. https://doi.org/10.1080/10888691.2018.1537791

Dubos, R. J., \& Pines, M. (1965). Health and disease. Time Inc.

El-Hani, C.N., \& Machado, V. (2020). COVID-19: The need of an integrated and critical view. Ethnobiology and Conservation, 9, article 18, 1-20.

Estany, A. (2016). Epidemiología ¿social?: Hacia un enfoque interdisciplinario [Social? epidemiology: Towards an interdisciplinary view]. In: A. Estany, \& À. Puyol (eds.). Filosofía de la epidemiología social [Philosophy of social epidemiology], pp. 59-78. CSIC/Plaza y Valdez.

Gershenson, C. (2015). Reduccionismo: Sus ventajas y sus límites [Reductionism: Its advantages and limits]. Investigación y Ciencia. https:/www.investigacionyciencia.es/blogs/fisica-y-quimica/34/posts/ reduccionismo-sus-ventajas-y-sus-lmites-13230

Grant, M. C., Geoghegan, L., Arbyn, M., Mohammed, Z., McGuinness, L., Clarke, E. L., et al. (2020). The prevalence of symptoms in 24,410 adults infected by the novel coronavirus (SARS-CoV-2; COVID19): A systematic review and meta-analysis of 148 studies from 9 countries. PLoS ONE, 15(6), e0234765. https://doi.org/10.1371/journal.pone.0234765

Greenhalgh, T. (2016). Cultural contexts of health: The use of narrative research in the health sector. (Health Evidence Network synthesis report 49.) WHO Regional Office for Europe.

Groneberg, D.A., Hilgenfeld, R., \& Zabel, P. (2005). Molecular mechanisms of severe acute respiratory syndrome (SARS). Respiratory Research, 6, article number 8. https://doi.org/10.1186/1465-9921-6-8

Hani, C., Trieu, N. H., Saab, I., Dangeard, S., Bennani, S., Chassagnon, G., \& Revel, M.-P. (2020). COVID19 pneumonia: A review of typical CT findings and differential diagnosis. Diagnostic and Interventional Imaging, 101(5), 263-268.

Hsu, J. (2008). The secrets of storytelling: Why we love a good yarn. Scientific American Mind, 19(4), 46-51.

Jayaweera, M., Perera, H., Gunawardana, B., \& Manatunge, J. (2020). Transmission of COVID-19 virus by droplets and aerosols: A critical review on the unresolved dichotomy. Environmental Research, 188, art. 109819. Advance online publication. https://doi.org/10.1016/j.envres.2020.109819

Jónasson, J.T. (2016). Educational change, inertia and potential futures. European Journal of Futures Research, 4(7). https://doi.org/10.1007/s40309-016-0087-z

Kaniewski, D., \& Marriner, N. (2020). Conflicts and the spread of plagues in pre-industrial Europe. Humanities \& Social Sciences Communications, 7(1), article number 162. https://doi.org/10.1057/ s41599-020-00661-1

Krieger, N. (2001). Theories for social epidemiology in the 21 st century: An ecosocial perspective. International Journal of Epidemiology, 30(4), 668-677. https://doi.org/10.1093/ije/30.4.668

Krieger, N. (2002). A glossary for social epidemiology: Part II. Epidemiological Bulletin, 23(2), n/pp.

Krieger, N., Rowley, D. L., Herman, A. A., Avery, B., \& Phillips, M. T. (1993). Racism, sexism, and social class: Implications for studies of health, disease, and well-being. American Journal of Preventive Medicine, 9(6 Suppl.), 82-122.

Labov, W. (2010). Narratives of personal experience. In P. C. Hogan (Ed.), Cambridge Encyclopedia of the Language Sciences (pp. 546-548). Cambridge University Press.

Langford, C. (2005). Did the 1918-19 influenza pandemic originate in China? Population and Development Review, 31(3), 473-505. https://doi.org/10.1111/j.1728-4457.2005.00080.x

Laurell, A. C. (1982). La salud-enfermedad como proceso social [Health-disease as a social process]. Cuadernos Médico Sociales, 19, 1-11.

Laurell, A.C. (2017). Social policy and health policy in Latin America: A field of political struggle. Cadernos de Saúde Pública, 33(Sup 2), e00043916. https://doi.org/10.1590/0102-311x00043916

Lenoir, Y., Rey, B., \& Fazenda, I. (eds.) (2001). Les fondements de l'interdisciplinarité dans la formation à l'enseignement [The foundations of interdisciplinarity in teacher education]. Sherbrooke: Éditions du CRP.

Littman, R. J. (2009). The Plague of Athens: Epidemiology and paleopathology. Mount Sinai Journal of Medicine, 76, 456-467. 
Lodge, D. (1986). Narration with words. In H. Barlow, C. Blakemore, \& M. Weston-Smith (Eds.), Images and understanding (pp. 141-153). Cambridge University Press.

Lodge, D. (1992). The art of fiction. Secker \& Warburg.

Longrigg, J. (1980). The Great Plague of Athens. History of Science, 18(1980), 209-225.

Maglio, P. (2008). La dignidad del otro: Puentes entre la biología y la biografía [The dignity of the other: Bridges between biology and biography]. Buenos Aires: Libros del Zorzal.

Mahajan, B. S., \& Chunawala, S. (1999). Indian secondary students' understanding of different aspects of health. International Journal of Science Education, 21(11), 1155-1168. https://doi.org/10.1080/09500 6999290129

Martin, W. (1986). Recent theories of narrative. Cornell University Press.

McKeown, T. (1988). The origins of human disease. Blackwell.

Memish, Z. (2016). MERS-CoV: From camels to humans. International Journal of Infectious Diseases, 45. Supplement, 1, 7-8. https://doi.org/10.1016/j.ijid.2016.02.047

Metz, D., Klassen, S., McMillan, B., Clough, M., \& Olson, J. (2007). Building a foundation for the use of historical narratives. Science \& Education, 16(3), 313-334. https://doi.org/10.1007/s11191-006-9024-z

Millar, R., \& Osborne, J. F. (1998). Beyond 2000: Science education for the future. King's College London.

Mutegi, J. W., \& Momanyi, L. O. (2020). Windows and mirrors: Three images of the US science curriculum as reflected through Kenya's Jua Kali. Cultural Studies of Science Education, 15(4), 861-874. https:// doi.org/10.1007/s11422-019-09967-2

Navarro, J. A. (2010). Influenza in 1918: An epidemic in images. Public Health Reports, 125(Suppl. 3), 9-14. https://doi.org/10.1177/00333549101250S304

Norris, S. P., Guilbert, S. M., Smith, M. L., Hakimelahi, S., \& Phillips, L. M. (2005). A theoretical framework for narrative explanation in science. Science Education, 89(4), 535-563. https://doi.org/10.1002/ sce. 20063

Oldstone, M. B. A. (2009). Viruses, plagues, and history: Past, present and future (Revised). Oxford University Press.

Oliveira, M. A. C., \& Egry, E. Y. (2000). A historicidade das teorias interpretativas do processo saúdedoença [Historicity of interpretive theories of the process health-disease]. Revista da Escola de Enfermagem de USP, 34(1), 9-15.

Ortiz-Revilla, J., Adúriz-Bravo, A., \& Greca, I. M. (2020). A framework for epistemological discussion on integrated STEM education. Science \& Education, 29(4), 857-880.

Parascandola, M. (2011). The epidemiologic transition and changing concepts of causation and causal inference. Revue d'Histoire des Sciences, 64(2), 243-262. https://doi.org/10.3917/rhs.642.0243

Poore, P. (2005). School culture: The space between the bars; the silence between the notes. Journal of Research in International Education, 4(3), 351-361. https://doi.org/10.1177/1475240905057815

Porta Serra, M. (2016). Si la epidemiología social existe, es integrativa: Y lo que importa es su influencia teórica y práctica [If social epidemiology exists, it is integrative: And what matters is its theoretical and practical influence]. In: A. Estany, \& À. Puyol (eds.). Filosofía de la epidemiología social, pp. 17-39. Madrid/México: CSIC/Plaza y Valdez.

Pumarola, T., \& Antón, A. (2018). La pandemia de 1918: Una incógnita 100 años después [The pandemic of 1918: An enigma 100 years later]. Revista de Enfermedades Emergentes, 17(2), 63-66.

Quammen, D. (2007). Deadly contact: How animals and humans exchange disease. National Geographic, 212(4), 78-105.

Ranta, E. M. (2016). Toward a decolonial alternative to development? The emergence and shortcomings of Vivir Bien as state policy in Bolivia in the era of globalization. Globalizations, 13(4), 425-439. https:// doi.org/10.1080/14747731.2016.1141596

Reiss, M. J. (2020). Science education in the light of COVID-19: The contribution of history, philosophy and sociology of science. Science \& Education, 29(4), 1079-1092. https://doi.org/10.1007/ s11191-020-00143-5

Revel Chion, A. (2013a). Estudios de caso en la enseñanza de la Biología y la Educación para la Salud en la escuela media [Case studies to teach biology and health education in secondaty school]. Bio-Grafía: Escritos sobre la Biología y su Enseñanza, 10, 47-53. https://doi.org/10.17227/20271034.vol.6num. 10bio-grafia42.49

Revel Chion, A. (2013b). La interdisciplina entendida como estrategia metodológica de integración de contenidos [Interdiscipline understood as a methodological strategy in content integration]. Ciencias Sociales y Educación, 2(4), 21-40.

Revel Chion, A., \& Adúriz-Bravo, A. (2014). ¿Qué historias contar sobre la emergencia de enfermedades?: El valor de la narrativa en la enseñanza de las ciencias [Which stories to tell on the emergence of diseases?: The value of narrative in science teaching]. Tecné, Episteme y Didaxis, 36, 47-59. 
Revel Chion, A., \& Adúriz-Bravo, A. (2017). Relatos para la enseñanza de una problemática americana: La enfermedad de Chagas-Mazza [Tales for teaching an American problem: Chagas-Mazza disease]. Tarbiya, 45, 83-93.

Revel Chion, A., \& Adúriz-Bravo, A. (2019). Las narrativas como dispositivo para el aprendizaje de las ciencias en la escuela secundaria [Narratives as a device for science learning in secondary schools]. In: Macedo, B. Silveira, S., Meziat, D., García Astete, M. y Bengochea, L. (eds.). Enseñanza y aprendizaje de las ciencias en debate: Volumen 3 [Science teaching and learning in debate: Volume 3], pp. 579-585. Alcalá de Henares: Universidad de Alcalá.

Rocca E., \& Anjum R.L. (2020). Complexity, reductionism and the biomedical model. In: R.L. Anjum, S. Copeland, \& E. Rocca (Eds.). Rethinking causality, complexity and evidence for the unique patient, pp. 75-94. Cham: Springer. https://doi.org/10.1007/978-3-030-41239-5_5

Rodríguez, M. I. (Ed.). (1994). Lo biológico y lo social: Su articulación en la formación del personal de salud [The biological and the social: Their articulation in the formation of health staff]. Organización Panamericana de la Salud.

Santos, M. (1978). Por uma geografia nova [For a new geography]. Hucitec.

Santos, M. (1995). Universal reason, local reason, the spaces of rationality. GeoJournal, 3(1), 108-110.

Tornali, C., Vecchio, F.A.G., \& Vecchio, I. (2020) Spanish flu and Covid-19: Historical correlations and bioethical implications. Journal of Clinical Research \& Bioethics, 11(3), 100052. https://doi.org/10. 35248/2155-9627.20.11.352

Thucydides (1933). History of the Peloponnesian War. (Translated by Richard Crawley.) London/New York: E.P. Dutton \& Co./J.M. Dent \& Sons.

Van Berkel, B., De Vos, W., Verdonk, A. H., \& Pilot, A. (2000). Normal science education and its dangers: The case of school chemistry. Science \& Education, 9(1-2), 123-159. https://doi.org/10.1023/A:10087 65531336

Viñao, A. (2002). Sistemas educativos, culturas escolares y reformas: Continuidades y cambios [Educational systems, school cultures and reforms: Continuity and change]. Morata.

Wang, L.F., \& Eaton, B.T. (2007). Bats, civets and the emergence of SARS. In: J.E. Childs, J.S. Mackenzie, \& J.A. Richt (Eds.). Wildlife and emerging zoonotic diseases: The biology, circumstances and consequences of cross-species transmission. Current topics in microbiology and immunology, vol. 315, pp. 325-344. Springer. https://doi.org/10.1007/978-3-540-70962-6_13

Wasserman, S. (1993). Getting down to cases: Learning to teach with case studies. Teachers College Press.

Widagdo, W., Okba, N. M. A., Raj, V. S., \& Haagmans, B. L. (2017). MERS-coronavirus: From discovery to intervention. One Health, 3, 11-16. https://doi.org/10.1016/j.onehlt.2016.12.001

Xu, R. H., He, J. F., Evans, M. R., Peng, G. W., Field, H. E., Yu, D. W., Lee, C. K., Luo, H. M., Lin, W. S., Lin, P., Li, L. H., Liang, W. J., Lin, J. Y., \& Schnur, A. (2004). Epidemiologic clues to SARS origin in China. Emerging Infectious Diseases, 10(6), 1030-1037. https://doi.org/10.3201/eid1006.030852

Zeidler, D. L., Sadler, T. D., Simmons, M. L., \& Howes, E. V. (2005). Beyond STS: A research-based framework for socioscientific issues education. Science Education, 89(3), 357-377.

Publisher's Note Springer Nature remains neutral with regard to jurisdictional claims in published maps and institutional affiliations. 